\title{
Investigating the use and perceptions of Activity Based Costing for road projects in Delta State, Nigeria
}

\author{
Oladosu, T I. ${ }^{1}$, Ngwu, C. ${ }^{2}$ and Ugochukwu S.C. ${ }^{3}$ \\ ${ }^{1}$ Senior Quantity Surveyor, CCC Construction Nigeria Limited, Delta State, Nigeria. \\ ${ }^{2,3}$ Senior Lecturers, Department of Quantity Surveying, Nnamdi Azikiwe University, Awka, Nigeria
}

DOI: 10.29322/IJSRP.11.10.2021.p11813

http://dx.doi.org/10.29322/IJSRP.11.10.2021.p11813

\begin{abstract}
The focus of this study is to investigate the adoption of activity based costing (ABC) for road construction projects in Delta State. Descriptive survey research design was employed, while the population consists of 205 construction professionals, managers and their accountants currently working with registered road construction companies operating in Delta State. A sample of 135 respondents was drawn from the entire population and reached through structured questionnaires; The data collected were analyzed using mean item scores, standard deviation and simple percentage frequencies with the aid of Statistical Package for Social Science (SPSS) version 21. Findings of the study revealed amongst others, that as result of adopting ABC, significant improvements are made in: pricing strategy, operating processes, project design, customer segments, compensation systems, and work force organization. It was also revealed that $\mathrm{ABC}$ captures all the activities involved and then allocates costs based on the level of activity, and this helps in the assessment of the profitability of the whole project. $\mathrm{ABC}$ allows more insight into the costs of performing activities in a construction company by providing greater insight into costs. $\mathrm{ABC}$ enables profitability analysis of projects, it gives accurate project costs and leads to elimination of wasteful activities. It was concluded that $\mathrm{ABC}$ system traces resource costs to project/product through activity cost drivers thus gives accurate project cost in construction industry and supports the pricing of contracts with improved cost allocation and profitability of the organisation. It was recommended that for successful implementation of the $\mathrm{ABC}$ system, construction companies must have a comprehensive review and re-engineering of their organization structure. Build a structure based on responsibility centers that directly reflect the project cost breakdown structure and cover all possible discipline of the project activities. Advanced information technology is also essential to increase the flexibility and adoptability of ABC.
\end{abstract}

Index Terms- Activity based costing, Model, Road projects, Delta State, Nigeria

\section{INTRODUCTION}

Road construction processes as well as estimating its costs are typically complex and consumes large amount of resources. It depends basically on monitoring the wage (labour) rates, material costs, similar projects, site conditions, inflation factor, project schedule, size of project, location of work site and the like. In these all estimation is done by the traditional method of costing which has been criticized for cost distortion and lack of relevance during the last 20 years (Blocher and Elhamma, 2013). A traditional system costing reports what money is spent on and by whom, but fails to report the cost of activities and processes (Chiarini, 2012).

Nowadays global environment has become very competitive due to the reduction of barriers of entry (communication, geographical and protected markets). This has resulted in increased incentives for industries to become more efficient. The global network improved as a consequence of reducing tariffs and import quotas which made the trade-market more accessible for companies and industries worldwide. An industry today might be successful in its local market, but the future is still uncertain because the open market enables other industries to enter the country and compete against local firms. This puts pressure on local firms to improve their performance and become world-class competitors so as to offer the market larger variety of products, at higher quality and lower prices

To corroborate this, Askarany and Yazdifar, (2012) posit that for an industry to operate successfully in such competitive environment, an efficient cost system is required. This will provide the industry with useful cost information of the industry's operations or activities. Management accounting information helps the company to identify the necessity for change/development in the company's business environment and shows how the company should respond in business settings. Dang (2011) states that there is need for industry to obtain more efficiency in the competitive world and to overcome the weaknesses of the traditional volume-based costing system which usually 
allocates costs based on single- volume measures such as direct-labor hours, direct labor costs and machine hours and to achieve this. In view of this, many organizations including petroleum, automobile companies in the manufacturing industry have adopted a new costing method called Activity Based Costing (ABC). ABC is a more accurate, reliable, and efficient than the traditional method. ABC type of costing describes every part of the activities of the construction and identifies their unit cost (Nalini, Shreenivasan, Neeraj., Sathya, \& Bharathi., 2018). Compared to traditional costing system, ABC system employed multiple cost drivers and allocation basis to allocate overhead cost to final products and services

Activity Based Costing according to Krumwiede, (2013) is a costing approach that assigns resource costs to cost objects such as products, services, or customers based on activities performed for the cost objects. The premise of this costing approach is that a firm's products or services are the results of activities and activities use resources which incur costs. Costs of resources are assigned to activities based on the activities that use or consume resources (resource consumption drivers), and costs of activities are assigned to cost objects based on activities performed for the cost objects (activity consumption drivers). Activity-Based Costing is an accounting method used to trace costs to a product or process of an organization and it aimed at identifying the overhead costs (indirect costs) in order to reach their best allocations based on the activities required to produce a specific service or product. Rather than assigning costs directly to the products, they are assigned to the activities performed by the company. Then, the costs of the products are calculated by determining how much each product uses each activity. This method requires knowledge of the process to determine the distribution of costs and even allows for predictions of costs for the future.

Askarany and Yazdifar (2012) further explained that since activity based costing is one of the most talked about and popular accounting innovations in the last two decades, the introduction of and popularity of activity based costing is largely linked to the notion that information provided by $\mathrm{ABC}$ is more accurate and detailed than those provided by the traditional costing systems (Wegmann, 2017). However, despite such proposed advantages of $\mathrm{ABC}$, survey evidence suggests that the take-up of activity based costing has been low in practice systems (Shil and Das, 2012), and the construction industry is not an exception.

The success of a project is judged by meeting the criteria of cost, time, safety, resource allocation, and quality as determined by the owner. Thus, the purpose of construction project management is to achieve goals and objectives through the planned expenditure of resources that meet the project's quality, cost, time, scope, and safety requirements. The construction manager must control, deflect, or mitigate the effects of any occurrence or situation that could affect project success. However, the construction industry inevitably faces many challenges which today's construction manager needs to provide solutions to. Some are new to the industry and some are centuries old. The nature of the industry further complicates these challenges. The industry is fragmented and often inefficient and is also slow to adopt, implement and integrate new information technologies and products, devoting few resources to research and development compared to other (Nehler, 2012). Namazi, (2016) opined that the finding of low application rates of ABC appears to be at odds with the notion that advantages of $\mathrm{ABC}$ are higher than those of traditional techniques. On the one hand a substantial body of literature suggests that traditional management accounting techniques cannot cope with the requirements of today's managerial needs, but on the other hand new management accounting technique such as $\mathrm{ABC}$, as potential solution to this problem has not been highly diffused and adopted by potential users. Regarding construction of road projects in Delta State, the extent ABC is applied for effective delivery is not clearly known. It is in view of the forgoing that the study sought to investigate the application of ABC or road construction projects in the State.

\section{The Problem}

Over the years, companies have relied on the use of traditional accounting costing methods in allocating costs to various costs units. Undoubtedly, the use of these traditional costing systems has not yielded the much desired results. The problem with using the traditional costing system is that: it does not provide accurate cost data which will assist them in allocating activity costs and cost drivers to their products and services Pokorna (2016); it is a deficient costing systems as it does not consider changes in the environment and practices such as competitiveness (Askarany and Yazdifar, 2012); the company's pricing and market strategies can be misstated because the traditional costing system does not always give the correct cost of a product. Moreover, for companies to continue to improve customer service and build better products and services, they need a costing system that does not give distorted information that can have a negative influence on the company's decision-making processes (Nehler, 2012), hence the need for appropriate accounting systems. The use of an appropriate cost system helps the company to protect and maintain a competitive advantage (Prachi and Tanvi, 2014). One of the modern systems of costing that its various applications is developing in service activities is the activity-based costing system.

This system calculate the effects result from changes of activities, complexities, diversity and specific characteristics of each activity by using appropriate methods (Wegmann, 2017). Unlike the traditional costing, activity-based costing (ABC) allocates the resources of organization based on the activity to each unit. In a study on factors influencing the implementation and success of $\mathrm{ABC}$ in companies in Saudi Arabia, it was found that companies implemented ABC because of deficiencies in their existing costing systems and the changes in their environment and practices such as competitiveness (Askarany and Yazdifar, 2012). Pokorna (2016) contends that the implementation of ABC will provide managers with accurate cost data which will assist them in allocating activity costs and cost drivers to their products and services.

This publication is licensed under Creative Commons Attribution CC BY.

http://dx.doi.org/10.29322/IJSRP.11.10.2021.p11813

WWw.ijsrp.org 


\section{LITERATURE REVIEW}

\section{Overview of Road Construction}

Modern road-construction techniques can be traced to a process developed by Scottish engineer John McAdam in the early 19 th century. McAdam topped multi-layer roadbeds with a soil and crushed stone aggregate that was then packed down with heavy rollers to lock it all together. Contemporary asphalt roads capable of supporting the vehicles that emerged in the 20th century built upon McAdams' methods by adding tar as a binder. According to Alinaitwe (2014), the actual process of road building has changed dramatically over the past century, going from large gangs of workers with picks and shovels to enormous specialized machines.

Rebuilding existing roads starts with peeling up existing pavement, grinding it and dumping it straight into trucks for reuse later as aggregate for new roads. After grading the surface, pavers come in and lay down fresh, continuous sheets of asphalt followed directly by the rollers. Supporting Gandu and Musa-Haddary (2017), observed that building or expanding modern roads is a complex undertaking that can cost anywhere from $\$ 2$ to 12 million per mile depending on the number of lanes and the location. A great deal of consideration must be put into where roads should go in order to minimize disruptions and the make them as direct as possible, while simultaneously keeping slopes reasonable in hilly areas for performance and safety reasons.

Road construction is one of the sectors that provides important ingredients for the development of an economy. However, it is becoming more complex because of the sophistications of the construction process itself and the large number of parties involved in the construction process, i.e., clients, users, designers, regulators, contractors, suppliers, subcontractors, and consultants (Enshassi 2016).

Road Construction industries have become an important player and are vital for the economic development of any country particularly the developing countries, (Ogunlana, and Toor, 2017). This industry in developing countries suffers from a number of problems that affect the time, cost and the quality performances. Successful completion of construction projects within the specified budget has become a challenging task. It is uncommon that a project is completed well within the estimated time, budget and desired quality. Good management of road construction cost is an important task for the successful completion of a project. Most of the time, it is difficult to achieve good cost management and the project experience a huge amount of cost overruns. Effective cost planning relates the design of roads to their cost so that while taking full consideration of quality, changes, risks, utility and appearance, the cost of a project is planned to be within the economic limits of the expenditure.

\section{The Concept of Activity Based Costing}

The ABC method was developed by accountants in the financial sector to help distribute overhead costs more accurately. As a result, the costs in the ABC method are typically associated with monetary values. However, this method can easily be modified to include additional costs such as environmental factors, insurance etc. This is because ABC measures the amount of resources consumed by the products. From this amount, one can use the specific costs or environmental impact of the resource to calculate the total cost.

Activity-based costing according to Yousefiyan, (2011) is defined as a methodology that measures the cost and performance of activities, resources, and cost objects. Activity-Based Costing is an accounting method used to trace costs to a product or process of an organization. Rather than assigning costs directly to the products, they are assigned to the activities performed. Then, the costs of the products are calculated by determining how much each product uses each activity (Blocher, \& Elhamma, 2013). Specifically, resources are assigned to activities, then activities are assigned to cost objects based on their use. ABC recognizes the causal relationships of cost drivers to activities. The activities used in the production and delivery of those products, and computes the costs of various activities. The costs of the activities used in the production of a product are then assigned to that product in a manner that approximates a causal relationship Arab, Cokins, Câpusneanu, and Barbu, (2011) postulates that this method requires knowledge of the process to determine the distribution of costs. The resulting data leads to visibility into the causes of costs in the process and even allows for predictions of costs for future scenarios. Krumwiede and Roth (2012) define that

"Activity-based costing is a management accounting system that focuses on measuring the cost
and performance of activities, products, customers, and other cost objects. ...The basic premise
of ABC is that activities consume resources and cost objects use activities. Thus, ABC assigns
resource costs to cost objects based on the activities used by the cost objects".

The ABC method is preferred over Volume Based Costing, which traces resources directly to cost objects. The ABC method traces resources to activities then to cost objects for a more accurate cost distribution. A cost object is typically a product or process, while the activities are discrete actions which must be performed to create the cost objects. Resources are objects used by the activities which result 
in costs such as equipment, labor, materials, etc.

Supporting the above view, Mahdavi (2017) stated that drivers are used to trace resources to activities and activities to cost objects. Resource drivers trace the resources to the activities and activity drivers trace the activities to the cost objects. These drivers represent the causes of consumption and thus allow for accurate distribution along the ABC chain. Figure 2 lists some common examples of resource and activity drivers. It is important that these drivers be correlated to the actual causes of consumption by the objects. This allows for accurate tracing and a better understanding of the costs of the system.

To Gholizadeh and Sanei, (2019) ABC recognizes the causal or direct relationships between resource costs, cost drivers, activities, and cost objects in assigning costs to activities and then to cost objects. ABC assigns factory overhead costs to cost objects such as products or services by identifying the resources and activities as well as their costs and amounts needed to produce output. Using resource consumption cost drivers, a firm determines the resource costs consumed by activities or activity centres (activity cost pools) and calculates the cost of a unit of activity. The firm then assigns the cost of an activity to products or services by multiplying the cost of each activity by the amount of the activity consumed by each of the cost objects.

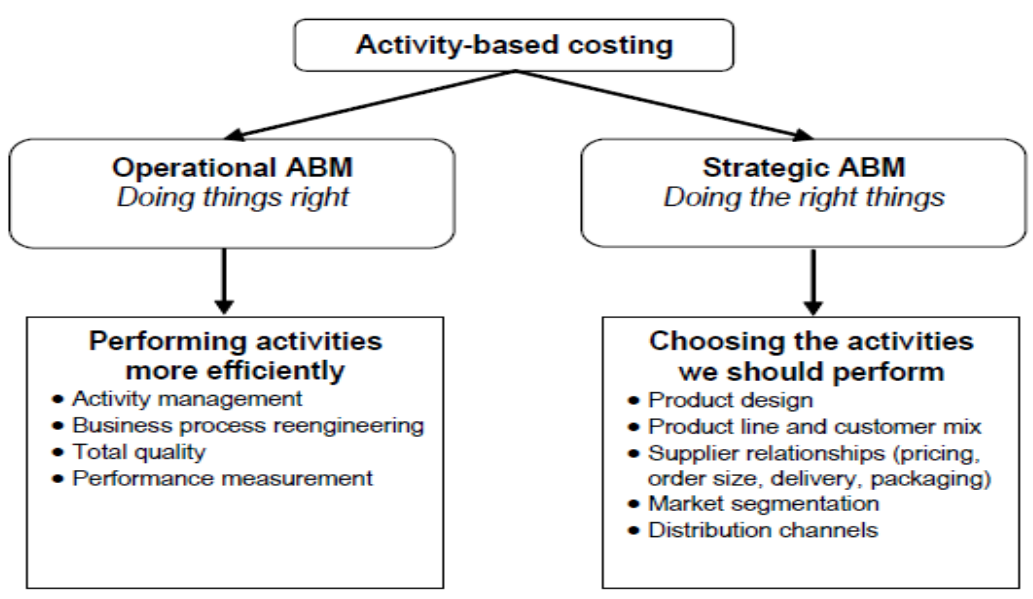

Fig 1: Operational Activity Based Costing

Source: Paul (2012)

The basic idea of $\mathrm{ABC}$ is that cost objects consume activities which consume resources and the consumption of these resources results in costs (Figures 1 and 2). This method requires additional knowledge of the process, but ends up producing more meaningful results. These results show both the true costs of products and provide insight as to why the products cost what they do. This provides opportunities to implement improvements and to predict future costs (Paul et al, 2012).

\section{Activity Based Costing In Construction}

In construction industry, CIDB, (2012) maintains that projects mainly focuses on two things, one is optimum utilization of resources and the other is speedy completion of project. In line to this trend, construction industry has seen Activity Based Management as a primary entity for every company or a project. There are a lot of non-value adding activities or wastes in construction practices and many among those were left unnoticed or unattended. Previous studies have shown that there were significant amounts of values loss due to construction process flow wastes and tremendous productivity improvements can be achieved by simply targeting at reducing or eliminating those wastes and/ or improve the process flow.

Activity Based Costing is a costing approach that assigns resource costs to cost objects such as products, services, or customers based on activities performed for the cost objects. As observed by Adioti, and Valverde, (2014) the premise of this costing approach is that a firm's products or services are the results of activities and activities use resources which incur costs. Costs of resources are assigned to activities based on the activities that use or consume resources (resource consumption drivers), and costs of activities are assigned to cost objects based on activities performed for the cost objects (activity consumption drivers). ABC recognizes the causal or direct relationships between resource costs, cost drivers, activities, and cost objects in assigning costs to activities and then to cost objects. ABC assigns factory overhead costs to cost objects such as products or services by identifying the resources and activities as well as their costs and amounts needed to produce output. Using resource consumption cost drivers, a firm determines the resource costs consumed by activities or activity centres (activity cost pools) and calculates the cost of a unit of activity. The firm then assigns the cost of an activity to products or services by multiplying the cost of each activity by the amount of the activity consumed by each of the cost objects. 
Activity Based Management is organizational workforce. It has been broadly defined as a field of organizational activity and professional practice covering functions related primarily to training, career development, and organizational development. Activity Based Costing is not structured in construction industry but the awareness about the need and importance of planning is growing. Though the construction sector is booming, with urbanization at its peak, the industry is not bereft of its share of woes. The biggest problem that the industry confronts is the acute shortage of skilled and trained manpower. Getting skilled and trained workforce these days has become an uphill task.

Similarly, projects found in the construction industry, the repetitive activities are repeated throughout the project. In accordance with Construction Industry Development Board (CIDB), (2012), these activities represent the work to be performed and enable the project to run smoothly. This in turn helps to speed up the project performance and minimize the project duration. For the construction projects, an effective resource management is always crucial for planners. Comparing the characteristics of the resource management issues in highly automated industry, the complexity of resource management in labour intense construction projects arises from the diversity of resource acquirement.

The infrastructure growth of a country depends on the development of construction industry. Implementation of infrastructure projects are usually failing in each stage and ultimately failure occur, which leads to cost and time overrun. Success of a project heavily depends on the ability to complete a project on scheduled time within the budget as per the required quality. Efficiency of a construction firm is to complete in time. Delay of a project during its progress would suffer material loss, machinery idling including tools and plants and equipment. The time overrun is the main cause of cost over run and it affects both clients and contractors.

According to Yousefiyan, (2011) there are many challenges that are faced by construction industry in Nigeria and there are so many factors that affect the planning. Productivity remains an intriguing subject and a dominant issue in the construction sector, promising cost savings and efficient usage of resources. Manufacturing cost involves the conversion of raw materials into finished products through the efforts of workers and the usage of production equipment. The cost of a manufactured product consists of three basic elements:

a. direct material,

b. direct labor and

c. manufacturing overheads.

Direct materials are those materials that become an integral part of a company's finished product and that can be conveniently traced to the finished product. Direct labour is reserved for those labor costs that can be physically traced to the creation of Productivity remains an intriguing subject and a dominant issue in the construction sector, promising cost savings and efficient usage of resources. Productivity is one of the most important issues in both developed and developing countries. products in a "hands-on" sense, and can then be easily traced without undue cost or inconvenience. Manufacturing overheads can be simply defined as all costs of manufacturing except direct materials and direct labour. Included in this classification are such costs as indirect materials, indirect labor, heat and light (utilities), property taxes, insurance, depreciation on factory facilities, repairs, maintenance and all other costs of operating the manufacturing divisions of a company.

ABC which states true cost accounting operations were established to capture and distribute costs to the output goods or services. These cost accounting operations use the classic model of cost distribution which was designed around the major factors of production: direct labour, direct materials and overheads. Product costs consist of the costs involved in the manufacturing of goods such as direct labour, direct material and manufacturing overheads. To cost the product using the cost structure base illustrated above, direct labour, direct materials and manufacturing overheads are attributed or allocated to the single unit of product. Traditional methods trace the direct labour and direct material into the certain single product unit by the product volume. That is:

Total unit cost $=\sum$ Direct Labour Cost $+\sum$ Direct Material Cost

\section{Product Volume}

ABC traces costs by using resource and activity drivers that reveal activities' and objects' consumption patterns on the basis of the cause and effect relationship. In activity costing systems, there are three building blocks: the resources, the activities and the cost objects.

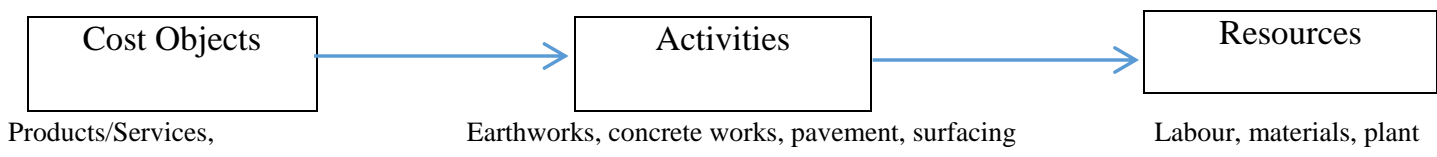

Fig 2: The ABC distribution chain in road construction

Source: Adapted from Paul (2012)

This publication is licensed under Creative Commons Attribution CC BY.

http://dx.doi.org/10.29322/IJSRP.11.10.2021.p11813

WWW.ijsrp.org 


\section{METHODOLOGY}

This study adopted a descriptive survey research design. The survey research design, according to Nworgu (2018), is one in which a group of people or items are studied by collecting and analyzing data from only a few people or items considered to be representative of the entire group using questionnaire or interview. This design is considered appropriate for this study since it sought to explore the opinions of the respondents on the application of activity based costing for road construction projects with the use of questionnaire. Delta State served as the study area. Being an oil producing state of Nigeria in the region known as the Niger Delta, South -South Geo-political zone, the state boasts of a number of road construction projects.

The population of respondents consists 205 construction professionals, managers and their accountants which includes architects, builders, engineers, project managers, and quantity surveyors who are currently working with registered road construction companies operating in Delta State. Preliminary survey also revealed that there are total of ten (10) major and active road construction companies duly registered in the State as shown in Table 1.

Table 1. Population distribution of the road construction companies and respondents for the study

\begin{tabular}{llllll}
\hline S/N & Construction Companies & Professionals & Managers & Accountants & Total \\
\hline 1. & SETRACO Nigeria limited & 15 & 6 & 2 & 23 \\
2. & LEVANT Construction Limited & 17 & 5 & 2 & 24 \\
3 & $\begin{array}{l}\text { Niger construction company } \\
\text { Limited }\end{array}$ & 14 & 6 & 2 & 22 \\
4 & $\begin{array}{l}\text { Consolidated Contractors Company } \\
\text { (CCC) Nigeria Limited }\end{array}$ & 13 & 4 & 2 & 19 \\
$\mathbf{5}$ & $\begin{array}{l}\text { Raycon \& Co Nigeria Limited } \\
\mathbf{6}\end{array}$ & 14 & 3 & 2 & 19 \\
$\mathbf{7}$ & Hi-tech Construction limited & 13 & 4 & 2 & 19 \\
8 & $\begin{array}{l}\text { ARC (Marine \& Civil Contractors } \\
\text { Limited }\end{array}$ & 15 & 5 & 2 & 22 \\
& $\begin{array}{l}\text { Obakpor Engineering limited } \\
9\end{array}$ & 13 & 5 & 2 & 20 \\
10 & $\begin{array}{l}\text { DNL Construction } \\
\text { China Civil Engineering } \\
\text { Construction Company (CCECC) }\end{array}$ & 12 & 4 & 2 & 20 \\
\hline & TOTAL & $\mathbf{1 4 0}$ & 3 & 2 & 17 \\
\hline
\end{tabular}

Source: Researchers' field survey (2020)

The sample size was calculated using Taro Yamane's formula as shown in equation 1.

$\mathrm{n}=\frac{N}{1+N(e)^{2}} \quad \ldots(1)$

when $\mathrm{n}=$ sample size

$\mathrm{N}=$ population

$\mathrm{e}^{2}=$ Margin of error (assumed 5\%)

$1=$ unity or constant

Therefore $=\frac{205}{1+205(0.05)^{2}}=135$ 
Being a survey research, data was through primary sources such structured questionnaires administered to the respondents and personal observations and secondary sources such as journals, textbooks and the internet.

To ascertain the validity of the research instrument, the researcher submitted draft copies of the instrument alongside with the research topic, objectives of the study, research questions and hypotheses to two experts in Quantity Surveying Department, Faculty of Environmental Sciences, Nnamdi Azikiwe University, Awka. The experts were requested to scrutinize the instrument with regards to the appropriateness of the structure, suitability of instructions, items statements and content coverage and make modifications as they deemed to enhance the validity of the instrument. Their inputs were used in modifying the items to the standard which were finally used for data collection.

The reliability of the instrument was established using a pilot test of 20 employees of road construction industries from Anambra State which is outside the study area but share similar characteristics with the study area. Data collected were analyzed using Cronbach alpha to establish the internal consistency of the instrument. The reliability values were obtained for clusters $\mathrm{B}_{1}$ to $\mathrm{B}_{5}$. The computations of the reliability co-efficient (see appendix).

The data generated for this study were analyzed using simple percentage frequencies, standard deviation and mean item scores (for ranking purposes). The results were also presented using Tables for proper elucidation.

Mean Score is expressed as:

$M S=\frac{5 n_{5}+4 n_{4}+3 n_{3}+2 n 2+n}{N}$

Where: $5 \ldots 1$ are the weightings on the Likert Scale

$\mathrm{n}=$ number of responses on a particular scale.

$\mathrm{N}=$ Total number of responses

IV. RESULTS AND DISCUSSION

Table 2. Questionnaire administration and response rate

\begin{tabular}{lll}
\hline Questionnaire & Frequency & Percentage (\%) \\
\hline Total no of copies of Questionnaire administered & 135 & \\
No of copiesreceived & 135 & 100 \\
No not received & 0 & \\
Total & 135 & $100 \%$ \\
\hline
\end{tabular}

Source: Researchers' field survey (2020)

Table 2 shows that, of the 135 copies of questionnaires distributed based on the sample size earlier obtained for the study, 135 representing $100 \%$ of the total respondents were completed and returned. The researcher proceeded with the analysis of the data as $100 \%$ response rate is regarded as very satisfactory for this study.

Table 3. Respondents' Profile

\begin{tabular}{lccc}
\hline Item & Variables & No of Responses & Percentages \\
\hline \multirow{2}{*}{ Experience } & (a) $0-5$ years & 34 & 25.00 \\
& (b) $6-10$ years & 39 & 30.00 \\
& (c) $11-15$ years & 29 & 20.00 \\
& (d) $16-20$ years & 23 & 15.00 \\
Total & (e) 20 years and above & 18 & 10.00 \\
\hline Field/discipline? & & $\mathbf{1 3 5}$ & 16.00 \\
& & & 10.00 \\
& 1. Architecture & 20 & 17.00 \\
& 2. Building & 14 & 15.00 \\
& 3. Civil Engineering & 21 & 12.00 \\
& 4. Electrical Engineering & 19 & 9.00 \\
& 5. Mechanical Engineering & 13 & 6.00 \\
\hline
\end{tabular}




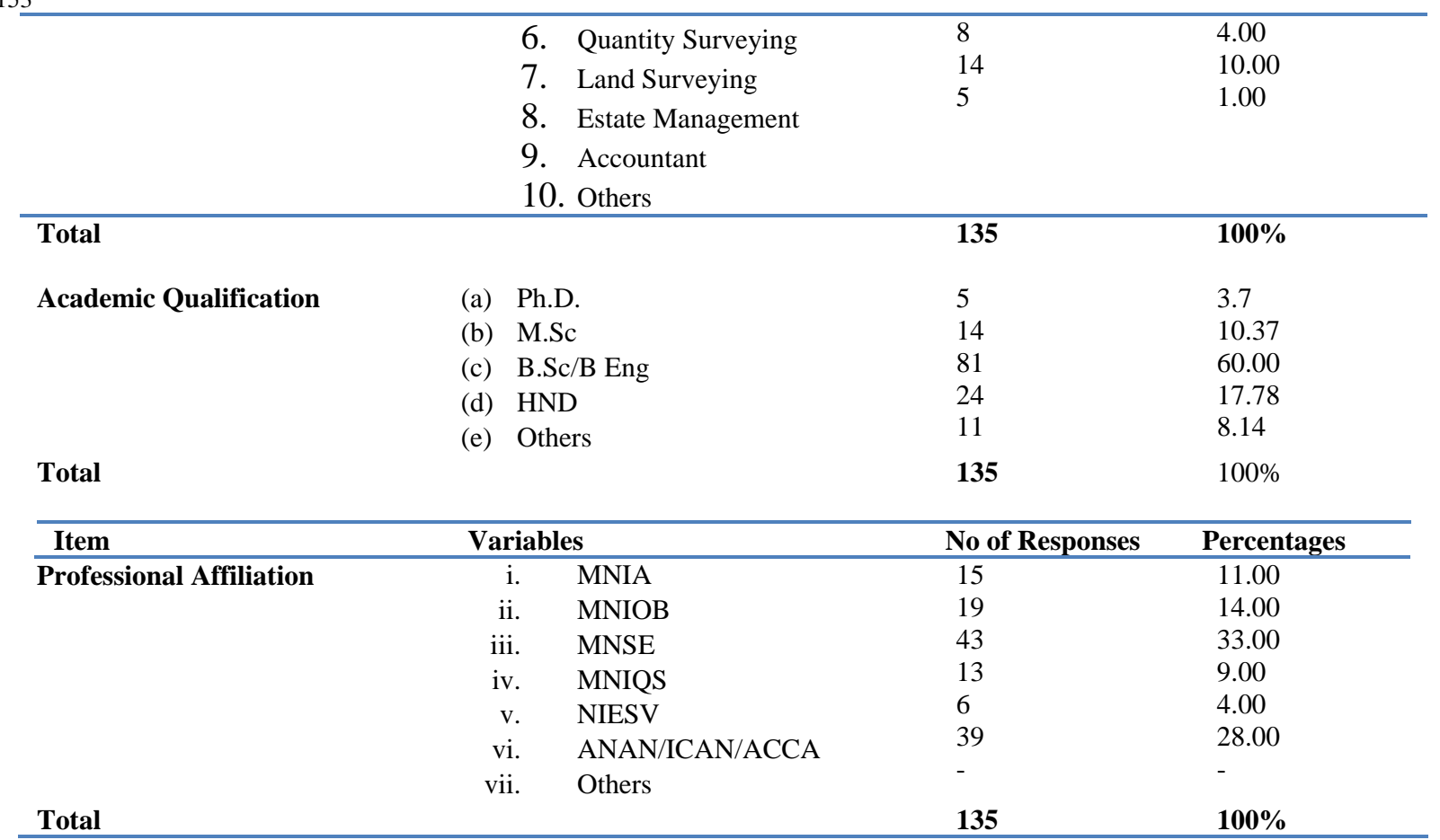

Source: Researchers' field survey (2020)

On how long the respondents have been working in the construction industry. Table 3 further reveals that 39 respondents representing $30.00 \%$ have worked between 6 to 10 years, 34 of them representing $25.00 \%$ have worked up to 5 years and 24 respondents have also worked between 16 to 20 years, while the remaining 18 respondents which represent $10.00 \%$ have worked up to 20 years and above. The trend therefore, shows that the respondents are experienced and as such can provide informed opinion about the state of activity base costing.

a. Respondents' Field/Discipline: Table 3 highlights that 20 respondents representing $17.00 \%$ are Civil Engineers, 21 of them are Architects which represents 16.00\% and Electrical Engineers 19 (15.00\%), Mechanical Engineers 16(9.00\%), Builders 14(10.00\%). Others are Quantity Surveyors who are 13(9.00\%), followed by land surveyors 10 (6.00\%), Estate Managers 8 $(4.00 \%)$ and $14(10.00 \%)$ respondents an accountant while $5(1.00 \%)$ represents unidentified field. This shows that respondents are made up of professionals that with basic knowledge on activity based costing.

b. Respondents' academic qualification: Table 3 shows that majority of the 81respondents representing 60.00\% have first degrees, followed by $14(10.37 \%)$ who have M.Sc. 5 (4.70\%) respondents obtained Ph.D. and the remaining respondents which represents $24(17.78 \%)$ obtained HND and $13(9.62 \%)$ indicated other qualifications. This highlights that the respondents are educated enough to handle contract auditing.

c. Respondents' Professional Affiliation: Even though 15(11.00\%) are Architects, they are affiliated with their professional body (MNIA). 19 (14.00\%) are affiliated to Nigeria Institution of Building (MNIOB).43 (33.00\%) are affiliated with the Engineering professional body (MNSE). 13(9.00\%) are affiliated with Nigerian Institute of Quantity Surveying (MNIQS) 6 (4.00\%) Estate profession (NIESV), while the remaining 39(28.00\%) respondents is affiliated to accounting profession (ANAN, ICAN/ACCA). This shows that the respondents are professionally competent in their various fields.

Table 4: Rating of respondents' understanding of the concept of "activity based costing" and its adoption in road construction projects in Delta State

\begin{tabular}{|c|c|c|c|c|c|c|c|c|c|}
\hline $\mathbf{S} / \mathbf{N}$ & Activity Based Costing Method & 5 & 4 & 3 & 2 & 1 & Rank & Mean & S D \\
\hline 1 & $\begin{array}{l}\text { As a result of using } \mathrm{ABC} \text {, changes are made } \\
\text { in pricing strategy }\end{array}$ & 71 & 41 & 23 & - & - & 1 & 4.08 & 1.48 \\
\hline 2 & $\begin{array}{l}\text { As a result of using } \mathrm{ABC} \text {, changes are made } \\
\text { in operating processes }\end{array}$ & 58 & 58 & 11 & 5 & 3 & 2 & 4.00 & 1.28 \\
\hline 3 & $\begin{array}{l}\text { As a result of using } \mathrm{ABC} \text {, changes are made } \\
\text { in project } \\
\text { Design }\end{array}$ & 58 & 58 & 11 & 5 & 3 & 2 & 4.00 & 1.28 \\
\hline
\end{tabular}

This publication is licensed under Creative Commons Attribution CC BY. 


\begin{tabular}{|c|c|c|c|c|c|c|c|c|c|}
\hline 4 & $\begin{array}{l}\text { As a result of using } \mathrm{ABC} \text {, changes are } \\
\text { made in customer } \\
\text { Segments }\end{array}$ & 43 & 51 & - & 20 & 21 & 4 & 3.92 & 1.26 \\
\hline 5 & $\begin{array}{l}\text { As a result of using } \mathrm{ABC} \text {, changes are made } \\
\text { in outsourcing decisions }\end{array}$ & 33 & 61 & 13 & 17 & 11 & 5 & 3.83 & 1.17 \\
\hline 6 & $\begin{array}{l}\text { As a result of using } \mathrm{ABC} \text {, changes are } \\
\text { made in compensation systems }\end{array}$ & 27 & 27 & 27 & 27 & 27 & 6 & 3.75 & \\
\hline 7 & $\begin{array}{l}\text { As a result of using } \mathrm{ABC} \text {, changes are } \\
\text { made in work force organization }\end{array}$ & 27 & 27 & 27 & 27 & 27 & 6 & 3.75 & \\
\hline
\end{tabular}

Cluster Mean

3.90

1.18

Source: Researchers' field survey (2020)

Table 4 presents the mean ratings and standard deviations of the respondents on the Activity Based Costing (ABC)" and it's Adoption in Delta State. The Table shows that the mean responses of the respondent ranged from 3.75 to 4.08 . All the items had mean values greater than 2.50 which is the criterion mean. The clusters mean scores on the Activity Based Costing (ABC)" and its Adoption in Delta State is 3.90 for respondents. Based on the fact that the cluster mean scores were above the criterion mean of 2.50, the respondents agree that the listed items 1-7 describes Activity Based Costing (ABC)" and its Adoption in Delta State.

Table 5: Impacts of activity based costing method on the performance of road construction project

\begin{tabular}{|c|c|c|c|c|c|c|c|c|c|}
\hline $\mathbf{S} / \mathbf{N}$ & Impacts of activity based costing method & 5 & 4 & 3 & 2 & 1 & S.D & $\begin{array}{l}\text { Mean } \\
\text { Score }\end{array}$ & Rank \\
\hline 1 & $\begin{array}{l}\text { It captures all the activities involved and } \\
\text { then allocates costs based on the level of } \\
\text { activity. }\end{array}$ & 30 & 20 & 23 & 31 & 31 & 1.45 & 2.58 & 11 \\
\hline 2 & $\begin{array}{l}\text { It helps in the assessment of the profitability } \\
\text { of the whole project. }\end{array}$ & 72 & 43 & 20 & - & - & 2.33 & 5.96 & 1 \\
\hline 3 & $\begin{array}{l}\text { ABC allows more insight into the costs of } \\
\text { performing activities in a construction } \\
\text { company }\end{array}$ & 70 & 41 & 19 & 3 & 2 & 2.23 & 5.58 & 2 \\
\hline 4 & ABC provides greater insight into costs. & 55 & 56 & - & 11 & 13 & 2.01 & 4.75 & 5 \\
\hline 5 & $\begin{array}{l}\text { Its basis for allocating overheads is more } \\
\text { reflective of cost behavior. }\end{array}$ & 50 & 50 & 31 & 2 & 2 & 1.88 & 4.23 & 7 \\
\hline 6 & ABC gives more insight into costs. & 33 & 32 & 10 & 30 & 30 & 1.58 & 3.08 & 10 \\
\hline 7 & $\begin{array}{l}\text { Its basis for allocating costs is more } \\
\text { realistic. }\end{array}$ & 33 & 61 & 13 & 17 & 11 & 1.67 & 4.19 & 8 \\
\hline 8 & $\begin{array}{l}\text { It uses multiple bases to allocate } \\
\text { overheads }\end{array}$ & 58 & 58 & 11 & 5 & 3 & 2.04 & 4.85 & 4 \\
\hline 9 & $\begin{array}{l}\text { ABC enables profitability analysis of } \\
\text { projects. }\end{array}$ & 32 & 49 & 21 & 21 & 13 & 1.74 & 3.69 & 9 \\
\hline 10 & ABC gives accurate project costs. & 50 & 61 & 3 & 11 & 10 & 1.93 & 4.42 & 6 \\
\hline 11 & $\begin{array}{l}\text { ABC leads to elimination of wasteful } \\
\text { activities. }\end{array}$ & 58 & 69 & - & 5 & 3 & 2.16 & 5.31 & 3 \\
\hline 12 & $\mathrm{ABC}$ can lead to increased profitability & 30 & 30 & 23 & 31 & 31 & 1.45 & 2.58 & 11 \\
\hline & Cluster & & & & & & 1.84 & 4.26 & \\
\hline
\end{tabular}

Source: Researchers' field survey (2020) 
ISSN 2250-3153

Table 5 presents the mean ratings and standard deviations of the respondents on the impacts of activity based costing method on the performance of road construction projects. The Table shows that the mean responses of the respondent ranged from 2.58 to 5.96 . All the items had mean values greater than 2.50 which is the criterion mean. The clusters mean scores on the Impacts of activity based costing method on the performance of road construction projects is 4.26 for respondents.

Based on the fact that the cluster mean scores were above the criterion mean of 2.50 , the respondents agree that the listed items $1-12$ are the Impacts of activity based costing method on the performance of road construction projects.

Table 6: Limitations and constraints in the implementation of activity based costing in road construction projects.

\begin{tabular}{|c|c|c|c|c|c|c|c|c|c|}
\hline $\mathbf{S} / \mathbf{N}$ & Limitations and constraints & 5 & 4 & 3 & 2 & 1 & S.D & $\begin{array}{l}\text { Mean } \\
\text { Score }\end{array}$ & Rank \\
\hline 1 & Lack of software packages. & 91 & 41 & 3 & - & - & 2.33 & 5.96 & 1 \\
\hline 2 & Takes up a lot of computer staff time & 91 & 41 & 3 & - & - & 2.33 & 5.96 & 1 \\
\hline 3 & High cost of ABC implementation. & 80 & 50 & 1 & 1 & 3 & 2.23 & 5.58 & 2 \\
\hline 4 & High cost consultants. & 58 & 58 & 11 & 5 & 3 & 2.01 & 4.75 & 5 \\
\hline 5 & Lack of local consultants. & 55 & 58 & 13 & 6 & 3 & 1.88 & 4.23 & 7 \\
\hline 6 & Difficulty in identifying activities. & 45 & 56 & 16 & 9 & 9 & 1.58 & 3.08 & 12 \\
\hline 7 & Difficulty in gathering data on cost-drivers. & 50 & 58 & 14 & 8 & 5 & 1.67 & 4.19 & 8 \\
\hline 8 & Difficulties of selection of cost drivers. & 60 & 41 & 19 & 4 & 10 & 2.04 & 4.85 & 4 \\
\hline 9 & $\begin{array}{l}\text { Changes required for company structure to } \\
\text { fit activities Selected }\end{array}$ & 46 & 58 & 17 & 7 & 7 & 1.74 & 3.69 & 11 \\
\hline 10 & Implementation is too expensive & 58 & 55 & 14 & 5 & 3 & 1.93 & 4.42 & 6 \\
\hline 11 & $\mathrm{ABC}$ software is expensive & 71 & 41 & 23 & - & - & 2.16 & 5.31 & 3 \\
\hline 12 & $\begin{array}{l}\text { ABC needs experienced accountants who } \\
\text { are expensive to employ. It is too } \\
\text { advanced }\end{array}$ & 27 & 27 & 27 & 27 & 27 & 1.45 & 2.58 & 13 \\
\hline 13 & $\begin{array}{l}\text { Lack of knowledge about } \mathrm{ABC} \text { and } \\
\text { personnel who know the system. }\end{array}$ & 27 & 27 & 27 & 27 & 27 & 1.45 & 2.58 & 13 \\
\hline 14 & It is time consuming to implement & 49 & 57 & 16 & 8 & 5 & 1.66 & 3.92 & 9 \\
\hline 15 & $\mathrm{ABC}$ is too complicated & 47 & 57 & 16 & 8 & 7 & 0.92 & 3.83 & 10 \\
\hline & \multicolumn{6}{|l|}{ Cluster } & 1.83 & 4.33 & \\
\hline
\end{tabular}

Source: Researchers' field survey (2020)

Table 6 presents the mean ratings and standard deviations of the respondents on the limitations and constraints in the implementation of activity based costing in road construction projects in Delta State. The Table shows that the mean responses of the respondent ranged from 2.58 to 5.96 . All the items had mean values greater than 2.50 which is the criterion mean. The clusters mean scores on the limitations and constraints in the implementation of activity based costing in road construction projects is 4.33 for respondents.

Based on the fact that the cluster mean scores were above the criterion mean of 2.50, the respondents agree that the listed items 1-15 are the limitations and constraints in the implementation of activity based costing in road construction projects in Delta State. 
Table 7 Critical success factors in the implementation of activity based costing

\begin{tabular}{|c|c|c|c|c|c|c|c|c|c|}
\hline $\mathbf{S} / \mathbf{N}$ & ABC Success factors & 5 & 4 & 3 & 2 & 1 & Rank & Mean & S.D \\
\hline 1 & $\mathrm{ABC}$ has led to cost savings in procurement & 83 & 42 & 20 & - & - & 1 & 4.08 & 1.48 \\
\hline 2 & $\mathrm{ABC}$ has led to cost savings in project design & 71 & 41 & 23 & - & - & 2 & 4.00 & 1.28 \\
\hline 3 & $\mathrm{ABC}$ has led to cost savings in operating process & 71 & 41 & 23 & - & - & 2 & 4.00 & 1.28 \\
\hline 4 & $\mathrm{ABC}$ has led to cost savings in marketing & 58 & 58 & 11 & 5 & 3 & 4 & 3.92 & 1.66 \\
\hline 5 & $\mathrm{ABC}$ has led to cost savings in project execution & 43 & 51 & - & 20 & 21 & 5 & 3.83 & 0.92 \\
\hline 6 & $\mathrm{ABC}$ has led to revenue improvements & 33 & 61 & 13 & 17 & 11 & 6 & 3.75 & 1.11 \\
\hline 7 & Overall, $\mathrm{ABC}$ was worth implementing & 33 & 61 & 13 & 17 & 11 & 6 & 3.75 & 1.42 \\
\hline & Cluster Mean & & & & & & & 3.90 & 1.18 \\
\hline
\end{tabular}

Source: Researchers' field survey (2020)

Table 7 presents the mean ratings and standard deviations of the respondents on the critical success factors in the implementation of activity based costing. The Table shows that the mean responses of the respondent ranged from 3.75 to 4.08 . All the items had mean values greater than 2.50 which is the criterion mean. The clusters mean scores on the critical success factors in the implementation of activity based costing is 3.90 for respondents. Based on the fact that the cluster mean scores were above the criterion mean of 2.50 , the respondents agree that the listed items 1-7 are the critical success factors in the implementation of activity based costing.

\section{SUMMARY, CONCLUSION AND RECOMMENDATIONS}

\section{The Concept "Activity Based Costing" and its Adoption Rate in Road Construction Projects in Delta State.}

The research findings showed that: as a result of using $\mathrm{ABC}$, changes are made in pricing strategy, operating processes, project design, customer segments, outsourcing decisions, compensation systems, and work force organisation. These findings are in agreement with Gholizadeh and Sanei, (2019) that ABC recognizes the causal or direct relationships between resource costs, cost drivers, activities, and cost objects in assigning costs to activities and then to cost objects. ABC assigns factory overhead costs to cost objects such as products or services by identifying the resources and activities as well as their costs and amounts needed to produce output. The findings are also consistent with the view of Krumwiede and Roth (2012) that Activity-based costing is a management accounting system that focuses on measuring the cost and performance of activities, products, customers, and other cost objects. The basic premise of ABC is that activities consume resources and cost objects use activities. Thus, $\mathrm{ABC}$ assigns resource costs to cost objects based on the activities used by the cost objects.

Impacts of Activity Based Costing Method on the Performance Of Road Construction Projects.

$\mathrm{ABC}$ captures all the activities involved and then allocates costs based on the level of activity, It helps in the assessment of the profitability of the whole project, $\mathrm{ABC}$ allows more insight into the costs of performing activities in a construction company, provides greater insight into costs, as its basis for allocating overheads is more reflective of cost behavior, gives more insight into costs, as its basis for allocating costs is more realistic, uses multiple bases to allocate overheads, enables profitability analysis of projects, gives accurate project costs, leads to elimination of wasteful activities, and can lead to increased profitability. These are in agreement with the view of Chongruksut (2012) who investigated the adoption of ABC in companies in Thailand. He noticed that the majority of companies, which used the traditional cost system were not satisfied with their costing system. They claimed that their system needs improvement. In contrast to this group, users of $\mathrm{ABC}$ had a quite high level of satisfaction with their system, especially in terms of more accurate product costs, cost control improvement, better performance measurement, continuous improvement and increase in competitive capability as well as increase in profitability. This could further be substantiated by the view of Fadzil and Rababah (2012) who measured the satisfaction of Jordanian $\mathrm{ABC}$ users in three areas: calculating methods, cost reduction, and gained benefits. His results show a high level of satisfaction with the three areas of utilization. The above findings are also consistent with the view of Nassar (2011) who considered the approach to be the core of the operational management support system, adding value to the account management system. Companies applying $\mathrm{ABC}$ enjoy the benefits of specifying and tracking all cost drivers leading to cost variances. 


\section{Limitations and Constraints in the Implementation of Activity Based Costing in Road Construction Projects}

Respondents agree that: lack of software packages, takes up a lot of computer staff time, high cost of ABC implementation, high cost consultants, lack of local consultants, difficulty in identifying activities, difficulty in gathering data on cost-drivers, difficulties of selection of cost drivers, changes required for company structure to fit activities selected, implementation is too expensive, $\mathrm{ABC}$ software is expensive, it needs experienced accountants who are expensive to employ, it is too advanced, lack of knowledge about ABC and personnel who know the system, it is time consuming to implement and it is too complicated. These findings are in agreement with the view of Cohen et al (2005), who stated that regardless of the numerous benefits of ABC that are widespread in the literature there are companies that strongly oppose to the possibility of $\mathrm{ABC}$ adoption. According to the findings of Cohen research, the main reasons for rejecting the adoption of $\mathrm{ABC}$ could be summarized by the following reasons: satisfaction with the existing costing system, ABC implementation being associated with high costs, lack of time to undertake an assessment of $\mathrm{ABC}$ implementation, $\mathrm{ABC}$ 's perceived inadequacy to provide more accurate cost information.

\section{Critical Success Factors in the Implementation Of Activity Based Costing.}

Respondents also agree that: $\mathrm{ABC}$ has led to cost savings in procurement, project design, operating process, marketing, project execution, revenue improvements; overall, $\mathrm{ABC}$ was worth implementing. These findings are in agreement with the view of Welfle and Keltyka (2000) that ABC is a solution which would lead a company to compete in adverse environments; therefore, allowing it to continuously improve in most of the project management perspectives such as quality, time, profitability as well as overall company performance. The finding is also in line with the submission of Jaffres (2011) who stated that ABC implementation has resulted in cost saving as well as a better utilization of resources.

\section{Conclusion}

ABC system emerged as an important tool in business. It is credited with providing greater insight into what drives costs and eliminating non-value adding activities and wastage. The system gives accurate product costs and supports the pricing of contracts, with improved cost allocation and cost reduction, profitability of the organisation improves with the implementation of the $\mathrm{ABC}$ system. $\mathrm{ABC}$ is a methodology that traces resource costs to products through activity cost drivers. There are different stages of ABC implementation which includes initiation, adoption, adaptation, routinization and infusion. Success factors and problems have been explained in the context of these stages. This study targeted a broad section of the potential audience because ABC systems are not exclusive to construction industry. Indeed, $\mathrm{ABC}$ is applicable to other sectors such as government, financial institutions and educational organizations. There are different views in the literature in which $\mathrm{ABC}$ success is defined and measured. For examples, measures of $\mathrm{ABC}$ success in the literature including the following, managerial perception of success, financial benefits derived from $A B C$, satisfaction with $A B C$ system, frequency of using $\mathrm{ABC}$ information, actions taken based on $\mathrm{ABC}$ information.

\section{Recommendations}

Based on the foregoing, the following are advanced;

(a) Focusing on the activity based costing model and process is vital where the periodic evaluation is also a must, and for adequate cost control function and effective Activity Based Costing implementation, it is mandatory to have proper and well defined Cost break down structure (CBS) as well as coding system. Cost breakdown structure should be designed based on users' needs, thus allowing better cost monitoring, cost analysis and cost control in any construction firm.

(b) Advanced information technology is essential to increase the flexibility and adoptability of ABC Model and guarantee the presence of real time information. Selecting a qualified team to carry out the design and implementation phases is crucial for successful results. Training teams of all levels based on each role and qualification is very important. Also, the documentation of all the phases has a significant benefit and will help facilitate the re-evaluation and enhancing process.

(c) For successful implementation of the $\mathrm{ABC}$ System, construction companies must have a comprehensive review and reengineering of their organization structure. Build a structure based on responsibility centers that directly reflect the project cost breakdown structure CBS and cover all possible discipline of the project activities.

(d) Furthermore, there is a high cost associated with the design and implementation of the ABC system. However, the overall benefits and added value will provide savings in the long run. Therefore, top management buy-in and continuous support is essential and vital.

(e) Finally, there is need for professional bodies in construction industry to come up with blueprint for effective implementation of ABC Model. And also come up with conference and seminars in order to create awareness on the important of ABC Model application in the construction sector. 


\section{REFERENCES}

[1] Adioti, A.A. \&Valverde, R. (2014). "Time-driven Activity Based costing for the Improvement of IT Service Operations". International Journal of Business and Management, 9(1), 109-128.

[2] Alinaitwe, H.M. (2014) 'An Assessment of Clients' Performance in Having an Efficient Building Process in Uganda', Journal of Civil Engineering and Management.

[3] Askarany, D., \&Yazdifar, H., (2012). An investigation into the mixed reported adoption rates for ABC: Evidence from Australia, New Zealand and the UK. International Journal of Production Economics, 135(1), 430-439.

[4] Blocher, K. \& Elhamma, P.L. (2013). The role of organisational and cultural factors in the adoption of activity-based costing: The case of Moroccan firms". Accounting and Management Information Systems. 12(1), 4-12.

[5] Chiarini, A. (2012). "Lean production: mistakes and limitations of accounting systems inside the SME sector". Journal of Manufacturing Technology Management. 23(5):681-700.

[6] Chiarini, R. (2012). "When four principles are too many: A commentary". Journal of Medical Ethics. 38(4), 197-198

[7] Chongruksut, A. (2012). Note on a New Zealand replication of the Innes et al. UK activity - based costing survey. Management Accounting Research,14, 67 - 72.

[8] Cokins, G. Câpusneanu, S. \&Barbu, C.M. (2011). "Decisions based on synthesis documents information of the ABC (Activity-Based Costing) method". International Journal of Accounting and Financial Reporting. 1(1), 112-132.

[9] Construction Industry Development Board (CIDB). https://registers cidb.org za/Put

[10] Dang, V.T., (2011).Innovative the curriculum and method of training accounting - auditing for undergraduates. Discussion forum.

[11] Enshassi K.M. (2016) 'Effect of project characteristics on project performance in construction projects based on structural equation model', Journal of Construction Engineering andManagement, 126(3)

[12] Gandu and Musa- Haddary, (2017).Bossink, H.J.H. Brouwers, "Construction Waste: Quantification and Source Evaluation", Journal of Construction Engineering and Management. $122(1), 55-60$

[13] Gholizadeh and Sanei, (2019). "Flexibility In Manufacturing And Activity Based Costing: Modelling The Interrelationships", The Journal of Applied Business Research - Second Quarter, 24(2),81-96.

[14] Jaffres, B. (2011). Improved cost control with profitability and cost management (PCM) and the ABC method. Bull Business Integration Solutions, 1-4.

[15] Krumwiede, A. A. (2013). The Practicability of Activity-Based Costing (ABC) in the Nigerian Retail Banks.Business Intelligence Journal, 4(2), 351-354. Retrieved October 24, 2015, from http://www.saycorporation.com>Article-14

[16] Mahdavi , A.(2017). "Factors influencing management accounting change: a case of Thai public universities", Paper presented at the 4th New Zealand Management Accounting Conference, Hamilton, New Zealand, 18-19 November 2010.

[17] Nalini R., Shreenivasan K.A., Neeraj, P.,SivaSathya G., Siva Bharathi K. (2018) Analysis of the characteristics of projects in diverse industries', Journal of Operations Management, 16(1), 43-61.

[18] Namazi, M. (2016). Time-driven activity-based costing: Theory, applications and limitations. Iranian Journal of Management Studies, 9(3): 457-482

[19] Nehler.S. (2012).Applying the ABC in provider organisations.Healthcare Financial Management, 66(11), 112-120.

[20] Nworgu, B. G. (2015). Educational research: Basic issues and methodology. Owerri: Wisdom publishers.

[21] Ogunlana, S.O. and Toor, S. (2017) 'Construction professionals' perception of critical success factors for large-scale construction projects", Construction Innovation: Information, Process,Management. 9(2), 149 - 167.

[22] Pokorna J. (2016). Impact of Activity-Based Costing on Financial Performance in the Czech Republic.Acta Universities Agriculture et Silviculturae Mendelianae Brunensis, 64(2), 643-652.

[23] Prachi, S. \& Tanvi, P. (2014).Fundamentals of water supply network. Surat: SardarVallabhbhai National University of Technology.

[24] Shil, Y. \& Das.S.T. (2012). “Applying activity-based costing approach for construction logistics cost analysis". Construction Innovation.11(3):259-281.

[25] Wegmann, G. (2017). Development Arround the Activity-Based Costing Methods: A State-of- Activity-based costing. Vietnam Association of Certified Public Accountants (translated). Available from http://www.vacpa.org.vn/index.php ?o=modules\&n=forum\&f=forum_detail \&idforum=319 [Accessed 8 Jan 2020 ]

[26] Welfle, C., \& Keltyka, M. (2000). Adoption of activity management practices: a note on the extent of adoption and the influence of organizational and cultural factors, Management Accounting Research, 15, 383-399

[27] Yousefiyan, M. (2011). Activity-Based Costing System in Cement companies accepted in Tehran Stock Exchange, Administrative Science Faculty of Shahid Beheshti University 


\section{AUTHORS}

First Author - Oladosu, Timothy Ifedapo, Senior Quantity Surveyor, CCC Construction Nigeria Limited, Delta State, Nigeria. Second Author - Ngwu, Chukwuemeka, Senior Lecturer, Department of Quantity Surveying, Nnamdi Azikiwe University, Awka,Anambra State, Nigeria

Third Author - Ugochukwu, Stanley Chukwudi, Senior Lecturer, Department of Quantity Surveying, Nnamdi Azikiwe University, Awka,Anambra State, Nigeria

\section{APPENDIX}

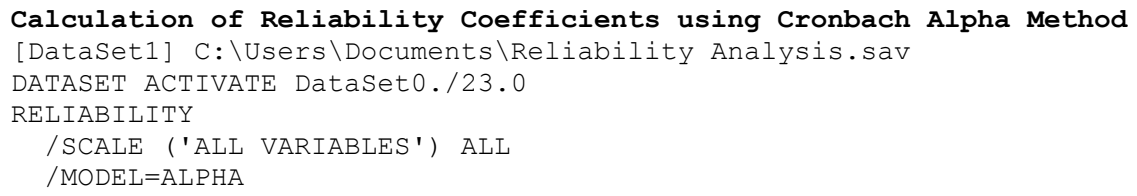

Reliability for cluster B1

\begin{tabular}{|c|c|c|c|}
\hline & & $N$ & $\frac{0}{8}$ \\
\hline \multirow{3}{*}{ Cases } & Valid & 20 & 100.0 \\
\hline & Excludeda & 0 & .0 \\
\hline & Total & 20 & 100.0 \\
\hline
\end{tabular}

Reliability Statistics

\begin{tabular}{|r|r|}
\hline $\begin{array}{r}\text { Cronbach's } \\
\text { Alpha }\end{array}$ & N of Items \\
\hline .839 & 17 \\
\hline
\end{tabular}

Reliability for cluster B2 Case Processing Summary

\begin{tabular}{|c|c|c|c|}
\hline & & $\mathrm{N}$ & $\%$ \\
\hline \multirow{3}{*}{ Cases } & Valid & 20 & 100.0 \\
\hline & Excluded ${ }^{a}$ & 0 & .0 \\
\hline & Total & 20 & 100.0 \\
\hline
\end{tabular}

Reliability statistics

\begin{tabular}{|r|r|}
\hline $\begin{array}{c}\text { Cronbach's } \\
\text { Alpha }\end{array}$ & N of Items \\
\hline .878 & 13 \\
\hline
\end{tabular}

Scale: RELIABILITY COEFFICIENT FOR ALL VARIABLES

Case Processing Summary

\begin{tabular}{|c|c|c|c|}
\hline & & $\mathrm{N}$ & $\%$ \\
\hline \multirow[t]{3}{*}{ Cases } & Valid & 20 & 100.0 \\
\hline & Excluded ${ }^{a}$ & 0 & .0 \\
\hline & Total & 20 & 100.0 \\
\hline
\end{tabular}

Reliability statistics

\begin{tabular}{|r|r|}
\hline $\begin{array}{r}\text { Cronbach's } \\
\text { Alpha }\end{array}$ & N of Items \\
\hline .859 & 17 \\
\hline
\end{tabular}


